DOI: $10.29141 / 2218-5003-2021-12-4-3$

JEL Classification: M10, D23, M14

\title{
The moderating role of LMX in the relationship between work values and organizational identification: A cross-cultural study
}

\section{Merve Karahan ${ }^{1}$, Serdar Bozkurt ${ }^{2}$}

${ }^{1}$ Marmara University, Istanbul, Turkey

${ }^{2}$ Yildiz Technical University, Istanbul, Turkey

\begin{abstract}
Employee values have an important effect on the success of organizations since they shape people's behavior. Knowing the work values of employees benefits organizations and leads to positive organizational outcomes. This study aims to examine the relationship between work values and organizational identification, and to determine the moderating role of leader-member exchange within this relationship. The methodological framework of the study includes social exchange theory based on dyadic relationships, and also social identity theory underlining the question of "Who am I?" to attach with an organization. To rationalize the proposed model, the data was collected through an online survey from 288 employees in Turkey and Germany. Descriptive statistics, confirmatory factor analysis, and structural equation modeling were performed to test the model. According to the results, employees' work values are positively associated with organizational identification, and leader-member exchange moderates this relationship. The practical and theoretical implications of the study are to raise awareness about the ability of leaders for desired organizational outcomes due to the values employees have, and to contribute to the work values literature in terms of cross-cultural perspective.
\end{abstract}

Keywords: work values; organizational identification; leader-member exchange (LMX); cross-cultural study; Turkey; Germany. Paper submitted: May 3, 2021

For citation: Karahan M., Bozkurt S. (2021). The moderating role of LMX in the relationship between work values and organizational identification: A cross-cultural study. Upravlenets - The Manager, vol. 12, no. 4, pp. 28-41. DOI: 10.29141/2218-5003-202112-4-3.

\section{Профессиональные ценности и организационная идентификация: межкультурное исследование роли LMX-модели Мерве Карахан ${ }^{1}$, Сердар Бозкурт ${ }^{2}$ \\ ${ }^{1}$ Университет Мармара, г. Стамбул, Турция \\ ${ }^{2}$ Технический университет Йылдыз, г. Стамбул, Турция}

Аннотация. Успех организации во многом определяется ценностными ориентирами сотрудников, формирующими их поведение. Осведомленность об этих ориентирах дает компании дополнительные преимущества и способна повысить эффективность ее деятельности. Статья посвящена изучению взаимосвязи между профессиональными ценностями работников и организационной идентификацией, а также роли модели LMX, ориентированной на обмен ресурсами между руководителем и подчиненными, в организационном взаимодействии. Методологический каркас исследования составили теория социального обмена, основанная на диадических отношениях, а также теория социальной идентичности, позволяющая индивиду ответить на вопрос «Кто я?» и примененная авторами в контексте организационных отношений. Информационной базой работы стали данные онлайн-опроса 288 сотрудников компаний, осуществляющих деятельность на территориях Турции и Германии. Использовались методы описательной статистики, подтверждающего факторного анализа и структурного моделирования. Выявлена положительная взаимосвязь между профессиональными ценностями работников и организационной идентификацией и установлено, что модель LMX играет в данном взаимодействии посредническую роль. Результаты исследования подтверждают гипотезу о возможности повышения эффективности деятельности организации за счет грамотного использования профессиональных ценностей работников, а также пополняют массив научной литературы об этих ценностях в разрезе межкультурного взаимодействия.

Ключевые слова: профессиональные ценности; организационная идентификация; модель LMX; межкультурное исследование; Турция; Германия.

Дата поступления статьи: 3 мая 2021 г.

Ссылка для цитирования: Карахан М., Бозкурт С. (2021). Профессиональные ценности и организационная идентификация: межкультурное исследование роли LMX-модели // Управленец. Т. 12, № 4. С. 28-41. DOI: 10.29141/2218-5003-202112-4-3. 


\section{INTRODUCTION}

Over the past 30 years, the world has witnessed radical changes in the political, economic, and social fields as a result of globalization and increasingly rapid technological developments. Nowadays, particularly with the pandemic, people still visit the websites, follow different TV and digital platforms, and get very comfortable access to thousands of books. Those examples that in connection with globalization have also strengthened the belief that individuals also have values that converge 1 . On the other hand, even though it is the reality that individual values are close to each other today, values do not change rapidly. Differences in value between individuals and countries have been the subject to many studies (see, for example, [Hofstede, 1980; Elizur et al., 1991]). In those studies, individual and workrelated values emerge as separate and independent fields from each other. The perspectives of researchers, who explore work values, differ from general value researchers in terms of both the methodology and the content. For this reason, although the research on values draws a general framework for the issue of work values, it cannot address the entire subject [Lyons, 2003]. Furthermore, work values have been the central issue of many studies nowadays. In the extant literature, the studies related to work values examine the relationships between work values and general values [Lyons, 2003; Almeida, Pinto, 2005], job satisfaction [O'Brien, Humphrys, 1982; Hegney, Plank, Parker, 2006], intention to quit [Eşitti, 2018], personality and demographic factors [Kubat, Kuruüzüm, 2010; Bayar, 2016], and generational differences [Twenge et al., 2010; Gursoy, Chi, Karadag, 2013; Erden-Ayhün, 2013; Öztürk, 2019]. The studies have mostly concluded that work values perception varies among generations, especially in the sample of students [Taş, Demirdöğmez, Küçükoğlu, 2017; Özer et al., 2013; Cennamo, Gardner, 2008]. Organizational identification has been increasingly emphasized in recent years, and studying the drivers of this concept seems to be beneficial. According to Lin, Shen and Hsu [2015], work values are vital to boost and direct employees' attitudes and behaviors. The link between employee and organization generates employees' identification through its values, mission, and vision [Hui et al., 2020].

In the light of the literature above, this study emphasizes the need for research investigating whether work values may positively influence employees' organizational identification. Moreover, we conceptualized the relationship between work values and organizational identification using the construct of leader-member exchange (LMX). It is a dyadic approach rooted in social exchange theory [Blau, 1964]. LMX theory includes reciprocal relationships between subordinates and their leader. The dyadic relationships expressed in this theoretical view vary from low-quality to high-quality exchange [Sparrowe,

\footnotetext{
${ }^{1}$ World Values Survey. (2020). Work values survey wave 7: Findings \& insights. https://www.worldvaluessurvey.org/WVSContents. jsp.
}

Liden, 2005]. Drawing on and extending this emerging LMX research, we propose that LMX moderates work values' effect on organizational identification. By studying LMX as a moderator of the relationship between work values and employees' identification with the organization, we intend to make three contributions:

- while recent studies with work values have been focused on the perceptions of generations' work values, this study investigates how work values are perceived in two different cultures, Turkish and German. Thus, our primary goal is to contribute to the literature on employees' work values from different cultures;

- we will contribute to the literature by examining the relationship between work values and organizational identification;

- we discuss how LMX may play a role as a moderating variable in the relationship between work values and organizational identification within the context of two different cultures, Turkish and German. So we will contribute to the LMX literature by conducting a comparative cultural study on this subject.

We first explain recent research on work values and organizational identification. We then review research that has examined the moderator effect of LMX in the relationship between work values and organizational identification. Then, the methodology part is presented, which is followed by a conclusion.

\section{LITERATURE REVIEW AND HYPOTHESES DEVELOPMENT}

Work Values. Values defined as general standards, formulating attitudes, behaviors, and beliefs underpin the basis of human behavior. For this reason, values influence the choices of individuals, the people they are in contact with, and their short- and long-term goals [Rokeach, 1973, p. 5; Posner, Randolph, Schmidt, 1987; Schwartz, Bilsky, 1987; Brown, 1995]. Schwartz [1999] defined values as the desired goals that guide human life and that change due to the conditions. Elizur et al. [1991] demonstrated the value as a significance level that society attributes to subject, behavior, and concern belonging to this society. In that vein, Hofstede [1980] conducted a cross-cultural research on values and defined the value as a great tendency towards preferring certain situations over others. In the light of those definitions, two important points related to values have been drawn to attention. First, all of the given descriptions focus on meaning, consequence, function, and goal. The other issue is that the values are considered as preference or precedence. Values may not always comply and may differ in societies and individuals. Therefore, values are a part of individualism and collectivism, and they provide rationality for socially unacceptable behaviors.

Work values as a specific type of values should be examined with a broader perspective [Lyons, 2003]. Many definitions are underlying the concept of work values as personal expectations regarding the individuals' expec- 
tations about the work or the career. According to some theoreticians work values are related to behaviors at work rather than personal emotions. They are a part of the individual's values system [Wollack et al., 1971; Lee, 1994]. On the other hand, work values have been examined through a horizon separately rather than a subset of individual values at work. Few studies involve the work values and how their relationship with work is [Ros, Schwartz, Surkiss, 1999]. Klenke [2005] states that work values have specific meaning compared to general values since work is vital in modern life.

Moreover, work values are crucial in understanding and predicting individuals' professional behaviors and job performance. For more than fifty years, researchers in industrial psychology, management, and organizational behavior have put great emphasis on work values and value systems. According to Hofstede [1980], values are building blocks of every culture, and thus the management style adopted in all cultures varies from society to society. By examining the values, the reasons underlying the behaviors can be identified, grouped, and analyzed. When the approaches related to work values in the literature are discussed, we cannot find a wide-held structure. Lyons [2003] has stated that most of the measurement tools regarding work values contain separate facilities apart from general values. However, still, work values are related to general values. He defined work values as reflecting individual values on business life. According to him, values transferred to business life make the workplace favorable. Lyons, Higgins and Duxbury [2010] proposed that work values refer to a higher-order construct which means a more general level of beliefs related to work. They preferred to use the term work aspects, which imply the modern work contexts such as working conditions, individual attributes of jobs, and work outcomes. In other words, work values define employees' preferences for such work aspects. The work aspects were categorized under four dimensions in Lyons et al. [2010]'s study: instrumental, cognitive, social/ altruistic, and prestige. Unlike the context-oriented work values, growth-oriented work values, expressed with personal increment, are seen in this four-dimensional model. Therefore, the model has allowed us to classify employees' personality and vocational interests, and work value profiles in a holistic manner.

Organizational Identification. Social identity theory provides the basis for organizational identification. According to Tajfel [1978, p. 63], individuals are members of social groups and they obtain knowledge from that membership through their affective commitment and values. Three dimensions are underlined in this definition: (1) cognitive - knowledge of membership; (2) practicalemotional attachment; and (3) evaluation - value implication. According to Tajfel and Turner [1979], a part of a person's self-concept originates from the groups they belong to, such as their family, country, sports team, neighborhood, or other groups. In other words, a wide range of identities and selves are shaped in a social group for the members. Individuals create in-group relationships since they feel that they are part of the group. Other groups, the person does not identify with, are also out-group. Thus, the person thinks as "us" for in-group and "them" for out-group. In organizational contexts, Van Dick [2001] reflected cognitive, affective, and evaluation dimensions to organizations. Furthermore, Ashforth and Mael [1989] provided an evidence-based social identity theory for organizational identification concept. The concept tries to find a remedy of the question "Who are we?" or "Who am I?" to attach with an organization, a group, or person [Albert, Ashforth, Dutton, 2000]. As a result, Foote [1951] stated that the individual classifies herself/himself as a member of the organization. This personal classification motivates her/him to act on behalf of the organization.

Employees create their self-images through their image and values when they experience organizational identification [Cheney, 1983; Akbaş et al., 2020]. Accordingly, organizational identification is reflected on decision making when the employees evaluate the preferred alternative for the sake of the organization [Cheney, Tompkins, 1987]. Identification differs from the assimilation since the individual internalizes organizations' values and goals within the identification. Indeed, the process of identification should be under the control of employees and more neutral [Polat, Meydan, 2010]. Pratt [1998] defined organizational identification as a convergence process of individuals with organizational values. As a result, employees can substitute their activities on behalf of the organization as their own. The organization's goals become the employee's goals, and the strongly identified employee is motivated to work effectively to achieve such goals [Edwards, 2005].

Work values are an antecedent and enhancer of employees' attitudes and behaviors [Lin, Shen, Hsu, 2015]. At the same time, values are considered to be the essential factors, representing beliefs that explain employees' behavior and their assessment of the task [AI-Zoubi, 2016]. Therefore, a long-term relationship between employees and organizations reveals employees' identification with an organization due to their reasonableness of values, mission, and vision [Hui et al., 2020]. Based on the aforementioned literature, we expect employees' work values to be related to their identification with the organization. Accordingly, our first hypothesis is the following:

H1: Work values have positive effects on organizational identification.

Leader-Member Exchange (LMX). LMX theory presents a mutual relationship between a leader, providing resources related to work, and a subordinate, who gets into task demand and proves worthiness to create trust. The leader develops various relationships or exchanges resources with each member [Graen, Scandura, 1987]. The researchers have defined two different types of LMX in terms of leader-subordinate relationships, similar to the 
in-group and out-group dichotomy. Dienesch and Liden [1986] have stated that in-group subordinates expand responsibilities, respect, liking, reciprocal influence, loyalty, and contributory behavior. In contrast, the low-quality relationship between superior and subordinate affect the subordinates' outcomes less. As a result, compared to other leadership theories, LMX has a unique context since it examines leader-subordinate relationships with a dyadic perspective [Markham et al., 2010]. Accordingly, this concept is explained by social exchange theory [Blau, 1964], and it provides a foundation for LMX [Sparrowe, Liden, 2005]. According to social exchange theory, people, who are treated favorably by others, will respond in the same manner. Thus, it can be inferred that employees, having a high-quality relation with the leader, get more resources and support from the leader and, in exchange, they return positive responses. It explains why previous studies revealed desirable positive organizational outcomes with LMX [Cha, Borchgrevink, 2018; Kim, Koo, 2017; Wang, 2016].

Extending the literature, sharing crucial work values is one of the main factors explaining the high-quality relationship between subordinates and their superiors [Dienesch, Liden, 1986; Graen, Uhl-Bien, 1995]. The agreement of shared values and more profound beliefs are necessary for dyads, as well as for larger organizational structures. The agreement appears when parties' expectations match each other [Graen, Scandura, 1987]. Some studies have presented valuable contributions to work values and their relationship with LMX. For example, Dose [1999] has stated that there is an association between work value congruence and LMX positively.

Moreover, Erdogan, Kraimer, and Liden [2004] have revealed the moderator effect of LMX in the link between career satisfaction and work values similarity. On the other hand, under the LMX theory, employees who have high-quality relationships with their leaders feel obliged to give positive responses or treatments because they get more support and resources. Thus, employees develop more job-related attitudes and behaviors [Graen, Uhl-Bien, 1995]. Many prior studies have shown that LMX is an essential factor to explain commitment, organizational identification, and less intention to leave [Kim, Poulston, Sankaran, 2017; Wang, Kim, Milne, 2017]. Strong empirical evidence was also provided to support the relationships between LMX and identification towards the organization, LMX, and customer orientation [Farrell, Oczkowski, 2012]. Positive dyadic relationships with the leader help to generate more valued employees and feel in the group. Those employees have a propensity to identify with their organizations [Tangirala, Green, Ramanujam, 2007].

As discussed earlier, the social exchange theory serves as a proper theoretical background to explain why work values might affect organizational identification through LMX. Employees' identification with the organization increases when they create a good relationship with the leader. Thus, we expect LMX to affect the nature of the relationship between the work values and organizational identification. Thus, our second hypothesis is as follows:

H2: LMX moderates the relationship between work values and organizational identification.

\section{RESEARCH METHODOLOGY}

Research model. After an extensive literature review, the research model has been presented below (see Figure). The dependent variable is organizational identification, the independent variable is work values, and the moderator variable is a leader-member exchange in the model.

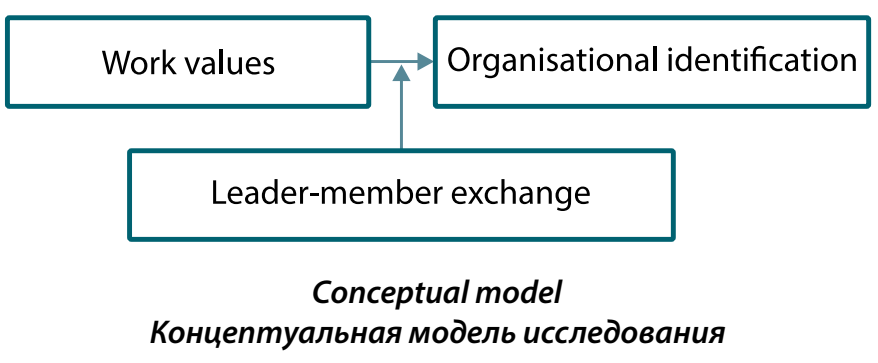

Sample. The research universe consists of all employees from the private sector, public sector, and nongovernmental organizations in Turkey and Germany. To reach the sample, a total of 400 survey links were sent to employees in both countries. Considering the time limitation, online surveys were sent several times over a period of time to increase the participation. After the questionnaires dropped due to the missing data and outliers, our final sample is composed of 288 participants; 179 employees from Turkey and 109 employees from Germany. The average age of all respondents was 31.88 years. $63.2 \%$ ( $N=182$ ) of all participants were female, and $36.8 \%$ $(N=106)$ were male. The majority of respondents have university degrees with $56.6 \%(\mathrm{~N}=163)$ and worked in the private sector $(74.7 \%)$, followed by the public sector with $19.4 \%$ and non-governmental organizations with $5.9 \%$. The supervisor of majority of the employees was male $(69.8 \%)$. Moreover, $30.6 \%$ of the respondents have been working for their current organization between two to five years. Finally, $33.7 \%$ of them have been working with their current manager for six months to two years (33.7\%). The data was collected as cross-sectional by using a convenience sampling technique in the study. The English version of the online survey was sent to employees working in Germany, and the Turkish version of the online questionnaires was distributed to employees working in Turkey. Respondents were assured in terms of confidentiality of the responses.

Scales. Employees from Germany answered the items from original English scales, while people who work in Turkey participated in Turkish adaptation forms of the initial questionnaires. All scales used within the study were measured with a six-point Likert scale ranging from $1=$ strongly disagree to $6=$ strongly agree. Previously developed scales were used, and the survey questionnaire consisted of 43 items under various scales to measure the 

alpha for this scale was found to be 0.95 in our study.

Organizational identification scale. Employees' identification with the organization was measured with Mael and Ashforth's [1992] six-item scale. The Cronbach's alpha of the questionnaire was found as 0.87 for its internal consistency. Tak and Aydemir [2004] adopted the scale into Turkish, and it was used in some Turkish contextual studies [Taştan, 2012; Kanbur, 2016] with higher internal consistency ( $a=0.91 ; a=0.84)$ to prove its reliability and validity. Cronbach's alpha for this scale was found to be 0.86 in our study.

Leader-member exchange scale. A multidimensional measure of LMX-MDM developed by Liden and Maslyn [1998] was used to assess leader-member exchange. The original scale has consisted of 12 items under four dimensions, such as effect, loyalty, contribution, and professional respect, with coefficient alphas of $0.90,0.74,0.77$, and 0.89 , respectively, in the employee samples. Üçler [2018]'s study obtained an adapted Turkish version of the scale. This study has revealed two dimensions as professional respect, affect, \& contribution $(a=0.95)$ and loyalty \& concern $(a=0.71)$. The total coefficient alpha was 0.93 . Cronbach's alpha for this scale was found to be 0.94 in our study.

Control variables. Gender, age, education, sector, the gender of the department manager, professional time in the current organization, and professional time with the current manager were the control variables in this research. Additionally, the questions "Your family is originally from:" and "Where did you spend most of your life?" were asked to participants to understand how long they

have been experiencing the organizational culture they are in and its work values.

Data analysis. The data were analyzed with Statistical Package for the Social Sciences (SPSS) version 18.0 and Analysis of Moments Structure (AMOS) version 23.0. Two analyses were performed through AMOS; confirmatory factor analysis (CFA) allowed us to test validation of measurement model and path analysis fitting and modification of the structural model. At that point, structural equation modeling (SEM) assesses the hypothesized model's relevance fit to the dataset. Furthermore, after testing the scales' construct validity with factor analysis, each scale's internal consistency analysis was performed.

\section{RESEARCH FINDINGS}

Measurement model. First, descriptive statistics consisting of mean, standard deviation, and correlations between study variables are shown in Table 1 . Second, to assess the measures' reliability and validity, CFA was performed on the study's scales. After making necessary modifications, CFA results indicated good fit for the scales as can be seen in Table $2(X 2(288)=1402.47, X 2 / d f=2.19, P=0.00, \mathrm{GFI}=$ $0.80, \mathrm{CFI}=0.90, \mathrm{TLI}=0.89, \mathrm{RMSEA}=0.06)$. According to the analysis results, item numbers $1,3,9,10$, and 16 from the work values scale were eliminated because of lower standardized regression weights since these scores should be level of 0.50 or above [Hayes, 2018]. Therefore, all the remaining items loaded significantly on their latent variables.

Convergent and discriminant validities are estimated with composite reliability (CR) and average variance extracted (AVE) values. For the convergent validity of the scale, all CR values are expected to be higher than AVE values. At the same time, the AVE value must be higher than 0.5 [Hair et al., 2009]. For discriminant validity, the AVE values' square root calculated for each factor is greater than the correlations between the construct and other constructs in the model [Fornell, Larcker, 1981]. This evidence for convergent and discriminant validities and Cronbach's alphas are presented in Table 3.

Table 1 - Means, standard deviations, and correlations Таблица 1 - Дескриптивная статистика

\begin{tabular}{|l|c|c|c|c|c|}
\hline \multicolumn{1}{|c|}{ Variables } & Mean & SD & 1 & 2 & 3 \\
\hline (1) Work values & 4.15 & 0.99 & 1 & & \\
\hline (2) Organizational identification & 3.97 & 1.11 & $0.37^{* *}$ & 1 & $0.39^{* *}$ \\
\hline (3) LMX & 3.98 & 1.13 & $0.64^{* *}$ & 1 \\
\hline
\end{tabular}

Note: $N=288 ;{ }^{* *} p<0.01$

Table 2 - Goodness-of-fit indices of the research model Таблица 2 - Оценка адекватности модели исследования

\begin{tabular}{|l|c|c|c|c|c|c|c|c|c|}
\hline Compliance criteria & $\mathrm{X} 2$ & $\mathrm{X} 2 / \mathrm{df}$ & $\mathrm{P}$ & $\mathrm{GFI}$ & $\mathrm{CFI}$ & $\mathrm{TLI}$ & RMSEA & Item deleted & Reason for deletion \\
\hline Fit indices & 1402.47 & 2.19 & 0.00 & 0.80 & 0.90 & 0.89 & 0.06 & Work values $1,3,9,10,16$ & Lower SRW \\
\hline
\end{tabular}

Note: SRW = Standardized Regression Weights; $p<0.001$. 
Table 3 - Correlations among latent variables, and the values of $C R, A V E$, and Cronbach's alphas Таблица 3 - Показатели корреляции между латентными переменными и значениями композитной надежности (CR), извлеченной средней дисперсии (AVE) и коэффичиента альфа Кронбаха

\begin{tabular}{|l|c|c|c|c|c|c|}
\hline \multicolumn{1}{|c|}{ Variables } & Cronbach's Alpha (a) & CR & AVE & 1 & 2 & 3 \\
\hline (1) Work values & 0.95 & 0.67 & 0.51 & $(0.71)$ & & \\
\hline (2) Organizational identification & 0.86 & 0.85 & 0.50 & $0.21^{* * *}$ & $(0.71)$ & \\
\hline (3) LMX & 0.94 & 0.94 & 0.56 & $0.64^{* * *}$ & $0.26^{* * *}$ & $(0.75)$ \\
\hline
\end{tabular}

Note: Diagonal elements in the parentheses are the square root of the AVE. ${ }^{* * *} p<0.001$.

Test of hypotheses. After testing convergent and discriminant validities, the hypothesized conceptual model was evaluated. Firstly, to test the effect of work values on organizational identification, AMOS 23 was used for structural equation modeling. The result is displayed in Table 4.

Table 4 - Impact of work values on organizational identification Таблица 4 - Влияние профессиональных иенностей на организачионную идентификацию

\begin{tabular}{|l|c|c|c|}
\hline Hypothesized path & Direction & Beta estimate & Decision \\
\hline WV $>$ OID & + & $0.38^{* * *}$ & Supported \\
\hline
\end{tabular}

Note: ${ }^{* *} p<0.001$.

When the Hypothesis 1 presenting the effect of work values on organizational identification is examined, work values have positive effect on organizational identification $(\beta=0.38 ; p<0.001)$. Thus, Hypothesis 1 is supported.

The second objective of the present study is to reveal the role of LMX as a moderator between work values and organizational identification. Considering the possibility of multicollinearity problem, the variables' means were calculated as suggested by Aiken, West, and Reno [1991]. Furthermore, tolerance and variance inflation factor (VIF) was calculated to evaluate the level of multicollinearity, and it was seen that there is no multicollinearity problem as for VIFs $<3$ [Kline, 2015]. As examined in Table 5, LMX moderates the relationship between work values and organizational identification, and thus Hypothesis 2 is also confirmed.

Table 5 - LMX as a moderator between work values and organizational identification

Таблица 5 - Анализ модели LMX как посредника между профессиональными ченностями и организационной идентификацией

\begin{tabular}{|l|c|c|}
\hline \multirow{2}{*}{ Variables } & \multicolumn{2}{|c|}{ Organizational identification } \\
\cline { 2 - 3 } & Model 1 & Model 2 \\
\hline (1) Work values & $0.21^{* * *}$ & $0.24^{* * *}$ \\
\hline$(2) L M X$ & $0.26^{* * *}$ & $0.28^{* * *}$ \\
\hline$(1) \times(2)$ & - & $0.11^{* * *}$ \\
\hline$R^{2}$ & 0.18 & 0.19 \\
\hline$\Delta R^{2}$ & 0.18 & 0.18 \\
\hline$F$ & 31.69 & 22.56 \\
\hline
\end{tabular}

Note: ${ }^{* * *} p<0.001$.

\section{RECOMMENDATIONS AND CONCLUSION}

Understanding employee values and interpreting their behaviors are vital for organizational success [Vurgun, Öztop, 2011]. Work values, as important facets of the culture, shape the employee behaviors and direct employee activities [Schwartz, Bilsky, 1987; Brown, 1995]. Intangible work values can only be understood through attitudes and behaviors, and verbally expressed. According to Özkan and Gümüş [2013], values in business life vary from culture to culture, from person to person, in the sector people work, as to demographic characteristics, and time. Accordingly, work value systems are changing in developed and developing societies as well. Therefore, it is important to understand the consequences of work values in terms of different cultures.

Based on the previous empirical findings, the current study is aimed to reveal the direct relationship between work values and organizational identification and the moderator role of LMX on the relationship between those two constructs. While the previous research focused mostly on generational differences particularly in the sample of students [Taş, Demirdöğmez, Küçükoğlu, 2017; Özer et al., 2013; Cennamo, Gardner, 2008], job satisfaction [Hegney, Plank, Parker, 2006], intention to quit [Eşitti, 2018], personality and demographic factors [Bayar, 2016], the current paper contributed to the work values literature by focusing on employees' identification with the organizations in Turkey and Germany, through LMX theory. Specifically, we argued that employees' organizational identification increases when they experience different work values such as instrumental, cognitive, social/altruistic, and prestige. Those elements allow us to develop a broader understanding regarding the employees' personality and professional interests, and their work value profiles. We also argued that employees give more positive work-related behavior, based on LMX theory due to the quality of their relationships with their supervisors [Graen, Uhl-Bien, 1995]. Thus, LMX moderates the relationship between employees' values at work and their identification with the organization. The discussion section based is presented in upcoming sections.

First, the purpose of the study is to explore the effect of work values on organizational identification. Results revealed a positive impact of work values on organizational identification as hypothesized in $\mathrm{H} 1$. 
This result matches with the previous studies (see, for example, [Hui et al., 2020; Al-Zoubi, 2016; Lin, Shen, Hsu, 2015]). The positive association among those two is that work values positively boost employees' attitudes, behavior, and job evaluations. When people reflect their individual values on business life, employees' work values are generated, and the organization is getting favorable. Then, employees identify themselves with organizational values and goals, as a result they work effectively and efficiently on behalf of the organization [Edwards, 2005]. Hence, it can be inferred that work values and positive experiences like job satisfaction are expected to result in a positive organizational outcome like organizational identification. Second, the moderator role of LMX within the relationship between work values and organizational identification was proposed in $\mathrm{H} 2$. According to the findings, $\mathrm{LMX}$ moderates this relationship since LMX has associations with work values [Dose, 1999; Graen, Scandura, 1987; Dienesch, Liden, 1986] as well as organizational identification [Kim, Poulston, Sankaran, 2017; Wang, Kim, Milne, 2017; Farrell, Oczkowski, 2012]. From a social exchange perspective [Blau, 1964], in-group subordinates; presenting respect, reciprocal influence, and loyalty; create a high-quality relationship with their leaders. In contrast, a low-quality relationship causes less subordinate outcomes.

Furthermore, current Hofstede Insights ${ }^{1}$ have presented country comparison with the cultural values for the six dimensions. Compared to Turkey, Germany displays less power distance, uncertainty avoidance, indulgence, and more individualism, masculinity, and

\footnotetext{
${ }^{1}$ Hofstede Insights. (2020). Country comparison: Germany and Turkey. https://www.hofstede-insights.com/country-comparison/ germany,turkey/.
}

long-term orientation. Accordingly, employees from Turkey, as a collectivist society, belong to the in-group in exchange for loyalty. A high-quality relationship between leader and subordinates is more common in the Turkish business environment than in Germany. This point explains why the impact of work values on organizational identification is higher for the Turkish employees after LMX was involved. Therefore, we conclude that Turkish employees create higher-quality relationships, whereas people who work in German culture tend to be in low-quality relationships with their superiors.

Majority of the recent studies study work values through the value concept of Schwartz [1999], Elizur et al. [1991], and Rokeach [1973]. However, in this study, following Hofstede [1980], Lyon [2003], and Schein [2010], work values are considered as a unique concept under the umbrella of organizational culture. Lyon [2003] states that work values should be evaluated independent from general values. We contribute to work values literature with this perspective. Since very few studies reveal the relationship between work values and organizational identification, we intended to contribute to this field. A cultural perspective is presented by selecting developed and developing countries as a sample. We wanted to contribute to the literature, especially by revealing the moderator role of LMX on two different cultures. Even there are some valuable contributions of this study, it includes some limitations as well. The sample size is the main limitation of the study to generalize the results. In particular, we could not separate the sample into two sample groups. Thus, much greater sample size can be chosen from different sectors or countries to compare the results with a broad horizon for future studies.

\begin{tabular}{|c|c|c|c|c|c|c|c|}
\hline No. & Question & \multicolumn{6}{|c|}{ Score } \\
\hline 1 & When someone criticizes this organization, it feels like a personal insult & 1 & 2 & 3 & 4 & 5 & 6 \\
\hline 2 & I am very interested in what others think about this organization & 1 & 2 & 3 & 4 & 5 & 6 \\
\hline 3 & When I talk about this organization, I usually say "we" rather than "they" & 1 & 2 & 3 & 4 & 5 & 6 \\
\hline 4 & This organization's successes are my successes & 1 & 2 & 3 & 4 & 5 & 6 \\
\hline 5 & When someone praises this organization, it feels like a personal compliment & 1 & 2 & 3 & 4 & 5 & 6 \\
\hline 6 & If a story in the media/public opinion criticized this organization, I would feel embarrassed & 1 & 2 & 3 & 4 & 5 & 6 \\
\hline
\end{tabular}


Leader-Member Exchange Scale Шкала оченки модели LMX

\begin{tabular}{|c|l|c|c|c|c|c|c|}
\hline No. & \multicolumn{1}{|c|}{ Question } & \multicolumn{3}{|c|}{ Score } \\
\hline 1 & I like my manager/supervisor very much as a person & 1 & 2 & 3 & 4 & 5 & 6 \\
\hline 2 & My manager/supervisor is the kind of person one would like to have as a friend & 1 & 2 & 3 & 4 & 5 & 6 \\
\hline 3 & My manager/supervisor is a lot of fun to work with & 1 & 2 & 3 & 4 & 5 & 6 \\
\hline 4 & $\begin{array}{l}\text { My manager/supervisor defends my work actions to a superior, even without complete knowledge } \\
\text { of the issue in question }\end{array}$ & 1 & 2 & 3 & 4 & 5 & 6 \\
\hline 5 & My manager/supervisor would come to my defense if I were "attacked" by others & 1 & 2 & 3 & 4 & 5 & 6 \\
\hline 6 & My manager/supervisor would defend me to others in the organization if I made an honest mistake & 1 & 2 & 3 & 4 & 5 & 6 \\
\hline 7 & I do work for my manager/supervisor that goes beyond what is specified in my job description & 1 & 2 & 3 & 4 & 5 & 6 \\
\hline 8 & $\begin{array}{l}\text { I am willing to apply extra efforts, beyond those normally required, to meet my manager's/ } \\
\text { supervisor's work goals }\end{array}$ & 1 & 2 & 3 & 4 & 5 & 6 \\
\hline 9 & I do not mind working my hardest for my manager/supervisor & 1 & 2 & 3 & 4 & 5 & 6 \\
\hline 10 & I am impressed with my manager's/supervisor's knowledge of his/her job & 1 & 2 & 3 & 4 & 5 & 6 \\
\hline 11 & I respect my manager's/supervisor's knowledge of and competence on the job & 1 & 2 & 3 & 4 & 5 & 6 \\
\hline 12 & I admire my manager's/supervisor's professional skills & 1 & 2 & 3 & 4 & 5 & 6 \\
\hline
\end{tabular}

Source: [Liden, Maslyn, 1998].

Work Values Scale Шкала оченки профессиональных ценностей

\begin{tabular}{|c|c|c|c|c|c|c|c|}
\hline No. & Question & \multicolumn{6}{|c|}{ Score } \\
\hline 1 & $\begin{array}{l}\text { Having benefits (e.g. vacation pay, health/dental insurance, pension plan, etc.) that meet your } \\
\text { personal needs }\end{array}$ & 1 & 2 & 3 & 4 & 5 & 6 \\
\hline 2 & Doing work that makes a significant impact on the organization & 1 & 2 & 3 & 4 & 5 & 6 \\
\hline 3 & Having the authority to organize and direct the work of others & 1 & 2 & 3 & 4 & 5 & 6 \\
\hline 4 & Working on tasks and projects that challenge your abilities & 1 & 2 & 3 & 4 & 5 & 6 \\
\hline 5 & Having management that provides timely and constructive feedback about your performance & 1 & 2 & 3 & 4 & 5 & 6 \\
\hline 6 & Working with agreeable and friendly co-workers with whom you could form friendships & 1 & 2 & 3 & 4 & 5 & 6 \\
\hline 7 & Working in an environment that is lively and fun & 1 & 2 & 3 & 4 & 5 & 6 \\
\hline 8 & Having the opportunity to continuously learn and develop new knowledge & 1 & 2 & 3 & 4 & 5 & 6 \\
\hline 9 & Having the assurance of job security & 1 & 2 & 3 & 4 & 5 & 6 \\
\hline 10 & Having hours of work that are convenient to your life & 1 & 2 & 3 & 4 & 5 & 6 \\
\hline 11 & Doing work that you find interesting, exciting and engaging & 1 & 2 & 3 & 4 & 5 & 6 \\
\hline 12 & Having the freedom to make decisions about how you do your work and spend your time & 1 & 2 & 3 & 4 & 5 & 6 \\
\hline 13 & $\begin{array}{l}\text { Working in an environment that allows you to balance your work life with your private life and family } \\
\text { responsibilities }\end{array}$ & 1 & 2 & 3 & 4 & 5 & 6 \\
\hline 14 & Having access to the information you need to do your job & 1 & 2 & 3 & 4 & 5 & 6 \\
\hline 15 & Doing work that is prestigious and regarded highly by others & 1 & 2 & 3 & 4 & 5 & 6 \\
\hline 16 & Doing work that affords you a good salary & 1 & 2 & 3 & 4 & 5 & 6 \\
\hline 17 & Doing work that provides change and variety in work activities & 1 & 2 & 3 & 4 & 5 & 6 \\
\hline 18 & Working where recognition is given for a job well done & 1 & 2 & 3 & 4 & 5 & 6 \\
\hline 19 & $\begin{array}{l}\text { Doing work that allows you to use the abilities you have developed through your education and } \\
\text { experience }\end{array}$ & 1 & 2 & 3 & 4 & 5 & 6 \\
\hline 20 & Having the opportunity for advancement in your career & 1 & 2 & 3 & 4 & 5 & 6 \\
\hline 21 & Doing work that provides you with a personal sense of achievement in your accomplishments & 1 & 2 & 3 & 4 & 5 & 6 \\
\hline 22 & Doing work that allows for a lot of social interaction & 1 & 2 & 3 & 4 & 5 & 6 \\
\hline 23 & Having the ability to influence organizational outcomes (e.g. performance, productivity etc.) & 1 & 2 & 3 & 4 & 5 & 6 \\
\hline 24 & Working for a manager/supervisor who is considerate and supportive & 1 & 2 & 3 & 4 & 5 & 6 \\
\hline 25 & Doing work that allows you to help people & 1 & 2 & 3 & 4 & 5 & 6 \\
\hline
\end{tabular}

Source: [Lyons, Higgins, Duxbury, 2010]. 
Aiken L.S., West S.G., Reno R.R. (1991). Multiple regression: Testing and interpreting interactions. California: SAGE.

Akbaş H.E., Bozkurt S., Oktay S., Yılmazer S. (2020). Analyzing the effect of corporate social responsibility perception on organizational identification from employee perspective (pp. 65-81). In I. Altinbasak-Farina, S. Burnaz (Eds.). Ethics, social responsibility and sustainability in marketing, accounting, finance, sustainability, governance \& fraud: Theory and application. Singapore: Springer.

Albert S., Ashforth B.E., Dutton J.E. (2000). Organizational identity and identification: Charting new waters and building new bridges. Academy of Management Review, vol. 25, no. 1, pp. 13-17. https://doi.org/10.5465/amr.2000.2791600.

Almeida L., Pinto H.R. (2005). Life values inventory: Portuguese adaptation studies. Psychological Analysis, vol. 23, no. 2, pp. 28-34.

Al-Zoubi M. (2016). Work values of Jordanian fresh graduates. International Journal of Business and Management, vol. 11, no. 7, pp. 237-244. DOl:10.5539/ijbm.v11n7p237.

Ashforth B.E., Mael F. (1989). Social identity theory and the organization. Academy of Management Journal, vol. 14, no. 1, pp. 20-39. https://doi.org/10.2307/258189.

Bayar L.S. (2016). Demografik faktörlerin iş değerleri üzerine etkisi; Iş̧̧̧i sendikaları üzerine bir araştırma [The effect of demographic factors on work values level: A research on labour unions]. Adnan Menderes Üniversitesi Sosyal Bilimler Enstitüsü Dergisi - Adnan Menderes University Journal of Social Sciences Institute, vol. 3, no. 1, pp. 37-67. (in Turkish). https://doi. org/10.30803/adusobed.188788.

Blau P.M. (1964). Exchange and power in social life. New York: J. Wiley.

Brown D. (1995). A values-based approach to facilitating career transitions. Career Development Quarterly, vol. 44, issue 1, pp. 4-11. https://doi.org/10.1002/j.2161-0045.1995.tb00524.x.

Cennamo L., Gardner D. (2008). Generational differences in work values, outcomes and person-organization values fit. Journal of Managerial Psychology, vol. 23, no. 8, pp. 891-906. https://doi.org/10.1108/02683940810904385.

Cha J., Borchgrevink C.P. (2018). Leader-member exchange (LMX) and frontline employees' service-oriented organizational citizenship behavior in the foodservice context: Exploring the moderating role of work status. International Journal of Hospitality and Tourism Administration, vol. 19, issue 3, pp. 233-258. https://doi.org/10.1080/15256480.2017.1324337.

Cheney G. (1983). On the various and changing meanings of organizational membership: A field study of organizational identification. Communication Monographs, vol. 50, issue 4, pp. 342-362. https://doi.org/10.1080/03637758309390174.

Cheney G., Tompkins P.K. (1987). Coming to terms with organizational identification and commitment. Central States Speech Journal, vol. 38, issue 1, pp. 1-15. https://doi.org/10.1080/10510978709368225.

Dienesch R.M., Liden R.C. (1986). Leader-member exchange model of leadership: A critique and further development. Academy of Management Review, vol. 11, no. 3, pp. 618-634. https://doi.org/10.2307/258314.

Dose J.J. (1999). The relationship between work values similarity and team-member and leader-member exchange relationships. Group Dynamics: Theory, Research, and Practice, vol. 3, no. 1, pp. 20-32. https://doi.org/10.1037/1089-2699.3.1.20.

Edwards M.R. (2005). Organizational identification: A conceptual and operational review. International Journal of Management Reviews, vol. 7, issue 4, pp. 207-230. https://doi.org/10.1111/j.1468-2370.2005.00114.x.

Elizur D., Borg I., Hunt R., Beck I.M. (1991). The structure of work values: A cross cultural comparison. Journal of Organizational Behavior, vol. 12, issue 1, pp. 21-38. https://doi.org/10.1002/job.4030120103.

Erden-Ayhün S. (2013). Kuşaklar arasındaki farklılıklar ve örgütsel yansımaları [Differences between generations and organizational effects]. Ekonomi ve Yönetim Araştırmaları Dergisi - Journal of Economics and Management Research, vol. 2, no. 1, pp. 93-112. (in Turkish)

Erdogan B., Kraimer M.L., Liden R.C. (2004). Work value congruence and intrinsic career success: The compensatory roles of leader-member exchange and perceived organizational support. Personnel Psychology, vol. 57, issue 2, pp. 305-332. https:// doi.org/10.1111/j.1744-6570.2004.tb02493.x.

Eşitti B. (2018). Konaklama işletmelerinde iş değerlerinin işten ayrılma niyetine etkileri: İş-aile-iş çatışmasının aracı rolü [The effects of work values on intention to leave in accommodation businesses: The mediating role of work-family-work conflict]. Verimlilik Dergisi - Journal of Productivity, no. 3, pp. 235-257. (in Turkish)

Farrell M.A., Oczkowski E. (2012). Organisational identification and leader member exchange influences on customer orientation and organizational citizenship behaviors. Journal of Strategic Marketing, vol. 20, no. 4, pp. 365-377. https://doi.org/10. 1080/0965254X.2011.643917.

Foote N.N. (1951). Identification as the basis for a theory of motivation. American Sociological Review, vol. 16, pp. 14-21. https:// doi.org/10.2307/2087964.

Fornell C., Larcker D.F. (1981). Evaluating structural equation models with unobservable variables and measurement error. Journal of Marketing Research, vol. 18, no. 1, pp. 39-50. https://doi.org/10.2307/3151312.

Graen G.B., Scandura T.A. (1987). Toward a psychology of dyadic organizing (pp. 175-208). In L.L. Cummings, B.M. Staw (Eds.). Research in organizational behavior. Greenwich, CT: JAI Press.

Graen G.B., Uhl-Bien M. (1995). Relationship-based approach to leadership: Development of leader-member exchange (LMX) theory of leadership over 25 years: Applying a multi-level multi-domain perspective. Leadership Quarterly, vol. 6, issue 2, pp. 219-247. https://doi.org/10.1016/1048-9843(95)90036-5.

Gursoy D., Chi C., Karadag E. (2013). Generational differences in work values and attitudes among frontline and service contact employees. International Journal of Hospitality Management, vol. 32, pp. 40-48. https://doi.org/10.1016/j.ijhm.2012.04.002. 
Hair J.F., Black W.C., Babin B.J., Anderson R.E. (2009). Multivariate data analysis. Upper Saddle River, NJ: Prentice Hall.

Hayes A.F. (2018). Introduction to mediation, moderation, and conditional process analysis: A regression-based approach (2 ${ }^{\text {nd }}$ ed.). New York, NY: The Guilford.

Hegney D., Plank A., Parker V. (2006). Extrinsic and intrinsic work values: Their impact on job satisfaction in nursing. Journal of Nursing Management, vol. 14, no. 4, pp. 271-281. DOI: 10.1111/j.1365-2934.2006.00618.x.

Hofstede G. (1980). Culture's consequences: International differences in work-related values. Beverly Hills, CA: SAGE.

Hui L., Qun W., Nazir S., Mengyu Z, Asadullah M.A., Khadim S. (2020). Organizational identification perceptions and millennials' creativity: Testing the mediating role of work engagement and the moderating role of work values. European Journal of Innovation Management, Vol. ahead-of-print No. ahead-of-print. https://doi.org/10.1108/EJIM-04-2020-0165.

Kanbur E. (2016). Algılanan örgütsel desteğin çalışanların iç girişimcilik performansları üzerindeki etkisinin incelenmesi [Examining the effects of perceived organizational support on intrapreneurship performance of employees]. Kafkas Üniversitesi Iktisadi ve Idari Bilimler Fakültesi Dergisi-KAÜïBFD - Kafkas University Journal of the Faculty of Economics and Administrative Sciences, vol. 7, no. 14, pp. 443-460. (in Turkish)

Kim M.S., Koo D.W. (2017). Linking LMX, engagement, innovative behavior, and job performance in hotel employees. International Journal of Contemporary Hospitality Management, vol. 29, no. 12, pp. 3044-3062. https://doi.org/10.1108/ IJCHM-06-2016-0319.

Kim P.B., Poulston J., Sankaran A.C. (2017). An examination of leader-member exchange (LMX) agreement between employees and their supervisors and its influence on work outcomes. Journal of Hospitality Marketing and Management, vol. 26, issue 3, pp. 238-258. https://doi.org/10.1080/19368623.2017.1228094.

Klenke K. (2005). Corporate values as multi-level, multi-domain antecedents of leader behaviors. International Journal of Manpower, vol. 26, no. 1, pp. 50-66. https://doi.org/10.1108/01437720510587271.

Kline R.B. (2015). Principles and practice of structural equation modeling. New York: The Guilford Press.

Kubat U., Kuruüzüm A. (2010). İş değerleri ile kişilik özellikleri arasındaki ilişkinin incelenmesi: Bir yapısal denklem modelleme yaklaşımı [An examination of the relationship between work values and personality traits: A structural equation modeling approach]. Süleyman Demirel Üniversitesi Iktisadi ve Idari Bilimler Fakültesi Dergisi - Suleyman Demirel University the Journal of Faculty of Economics and Administrative Sciences, vol. 15, no. 3, pp. 487-505. (in Turkish)

Lee P.H. (1994). Application of work values to consultation on ways of living. Guidance Quarterly, vol. 30, pp. 33-40.

Liden R.C., Maslyn J.M. (1998). Multidimensionafity of leader-member exchange: An empirical assessment through scale development. Journal of Management, vol. 24, issue 1, pp. 43-72. https://doi.org/10.1177/014920639802400105.

Lin J., Shen P.F., Hsu Y. (2015). Effects of employees' work values and organizational management on corporate performance for Chinese and Taiwanese construction enterprises. Sustainability, vol. 7, pp. 16836-16848.

Lyons S. (2003). An exploration of generational values in life and at work (Unpublished Doctoral Thesis). Carleton University Eric Sprott School of Business, Ottowa, ON.

Lyons S.T., Higgins C.A., Duxbury L. (2010). Work values: Development of a new three-dimensional structure based on confirmatory smallest space analysis. Journal of Organizational Behavior, vol. 31, issue 7, pp. 969-1002. https://doi.org/10.1002/ job.658.

Mael F.A., Ashforth B.E. (1992). Alumni and their alma mater: A partial test of the reformulated model of organizational identification. Journal of Organizational Behaviour, vol. 13, issue 2, pp. 103-123. https://doi.org/10.1002/job.4030130202.

Markham S.E., Yammarino F.J., Murry W.D., Palanski M.E. (2010). Leader-member exchange, shared values, and performance: Agreement and levels of analysis do matter. The Leadership Quarterly, vol. 21, no. 3, pp. 469-480. https://doi.org/10.1016/j. leaqua.2010.03.010.

O'Brien G.E.,HumphrysP.(1982).The effects of congruencybetween workvalues and perceived jobattributes upon thejob satisfaction of pharmacists. Australian Journal of Psychology, vol. 34, no. 1, pp. 99-101. https://doi.org/10.1080/00049538208254719.

Özer P.S., Eriş E.D., Neczan Ö., Özmen T. (2013). Kuşakların farklılaşan iş değerlerine ilişkin emik bir araştırma [An emic research on generational differences in work values]. Dumlupınar Üniversitesi Sosyal Bilimler Dergisi - Dumlupınar University Journal of Social Sciences, vol. 38, pp. 123-142. (in Turkish)

Özkan Ç., Gümüş M. (2013). Ege Bölgesindeki 4-5 yıldızlı otel işletmelerinde örgüt kültürünün iş değerlerinin dönüşümüne etkileri [In the Aegean Region 4-5 star hotel business organizational culture effects of work values transformation]. KMÜ Sosyal ve Ekonomik Araştırmalar Dergïsi - KMU Journal of Social and Economics Research, vol. 15, pp. 01-14. (in Turkish)

Özkan S. (2010). Illköğretim okulu öğretmenlerinin örgütsel bağlıı̆ı ve iş değerleri [The organizational commitment and work values of primary school teachers] (Unpublished master thesis). Mersin University Social Sciences Institution, Mersin.

Öztürk İ. (2019). Kuşaklararası iş değerleri ve örgütsel bağlılık ilişkisi: Vakıf üniversitelerinde bir inceleme [The relationship between intergenerational business values and organizational commitment: $A$ study in foundation universities]. Istanbul Ticaret Üniversitesi Sosyal Bilimler Dergisi - Istanbul Commerce University Journal of Social Sciences, vol. 18, issue 35, pp. 179-191. (in Turkish)

Polat M., Meydan C.H. (2010). Örgütsel özdeşleşmenin sinizm ve işten ayrılma niyeti ile ilişkisi üzerine bir araştırma [An empirical study on the relationship of organizational identification with cynicism and intention to leave]. Savunma Bilimleri Dergisi - The Journal of Defense Sciences, vol. 9, no. 1, pp. 145-172. (in Turkish)

Posner B.Z., Randolph W.A., Schmidt W.H. (1987). Managerial values across functions: A source of organizational problems. Group \& Organization Studies, vol. 12, no. 4, pp. 373-385. https://doi.org/10.1177/105960118701200402.

Pratt M.G. (1998). To be or not to be: Central questions in organizational identification (pp. 171-207). In D.A. Whetten, P.C. Godfrey (Eds.). Identity in organizations: Building theory through conversations. Thousand Oaks, CA: SAGE. 
Rokeach M. (1973). The nature of human values. New York: The Free Press.

Ros M., Schwartz S.H., Surkiss S. (1999). Basic individual values, work values, and the meaning of work. Applied Psychology: An International Review, vol. 48, no. 1, pp. 49-71. https://doi.org/10.1111/j.1464-0597.1999.tb00048.x.

Schein E.H. (2010). Organizational culture and leadership (4th ed.). San Francisco, CA: Jossey-Bass.

Schwartz S.H. (1999). A theory of cultural values and some implications for work. Applied Psychology: An International Review, vol. 48, no. 1, pp. 23-47. https://doi.org/10.1111/j.1464-0597.1999.tb00047.x.

Schwartz S.H., Bilsky W. (1987). Toward a universal psychological structure of human values. Journal of Personality and Social Psychology, vol. 53, no. 3, pp. 550-562. https://doi.org/10.1037/0022-3514.53.3.550.

Sparrowe R.T., Liden R.C. (2005). Two routes to influence: Integrating leader-member exchange and social network perspectives. Administrative Science Quarterly, vol. 50, issue 4, pp. 505-535. https://doi.org/10.2189/asqu.50.4.505.

Tajfel H. (1978). Differentiation between social groups: Studies in the social psychology of intergroup relations. London: Academic Press.

Tajfel H., Turner J.C. (1979). An integrative theory of inter-group conflict (pp. 33-47). In W.G. Austin, S. Worchel (Eds.). The social psychology of inter-group relations. Monterey, CA: Brooks/Cole.

Tak B., Aydemir B.A. (2004). Örgütsel özdeşleşme üzerine iki görgül çalışma [Two empirical studies on organizational identification]. 12. National Administrative and Organization Congress, Uludağ University, Bursa.

Tangirala S., Green S.G., Ramanujam R. (2007). In the shadow of the boss's boss: Effects of supervisors' upward exchange relationships on employees. Journal of Applied Psychology, vol. 92, issue 2, pp. 309-320. https://doi.org/10.1037/0021-9010.92.2.309.

Taş H.Y., Demirdöğmez M., Küçükoğlu M. (2017). Geleceğimiz olan Z kuşağının çalışma hayatına muhtemel etkileri [Possible effects of future architects' Z generation on business life]. OPUS - Uluslararası Toplum Araştırmaları Dergisi - International Journal of Society Researches, vol. 7, pp. 1031-1048. (in Turkish)

Taştan S. (2012). Bir pozitif psikoloji kavramı olarak örgütle özdeşleşmenin psikolojik güçlendirme algısı ve gönüllü performans davranışı arasındaki ilişkide ara değişken rolünün değerlendirilmesi: Gıda sektöründe yapılan bir araştırma [The examination of the moderating role of organizational identification as being a positive psychology concept on the relationship between psychological empowerment and voluntary performance behavior: A research in food sector]. Organizasyon ve Yönetim Bilimleri Dergisi - The Journal of Organization and Management Sciences, vol. 4, pp. 227-238. (in Turkish)

Twenge J.M., Campbell S.M., Hoffman B.J., Lance C.E. (2010). Generational differences in work values: Leisure and extrinsic values increasing, social and intrinsic values decreasing. Journal of Management, vol. 36, issue 5, pp. 1117-1142. https://doi. org/10.1177/0149206309352246.

Üçler Ç. (2018). Investigating the relations of psychological contract, organizational transparency and leader member exchange with employee performance behaviors (Unpublished doctoral thesis). Marmara University Social Sciences Institution, İstanbul.

Van Dick R. (2001). Identification in organizational contexts: Linking theory and research from social and organizational psychology. International Journal of Management Reviews, vol. 3, issue 4, pp. 265-283. https://doi.org/10.1111/1468-2370.00068.

Vurgun L., Öztop S. (2011). Yönetim ve örgüt kültüründe değerlerin önemi [Significance of values for management and organizational culture]. Suleyman Demirel University The Journal of Faculty of Economics and Administrative Sciences, vol. 16, pp. 217-230.

Wang C.J. (2016). Does leader-member exchange enhance performance in the hospitality industry? The mediating roles of task motivation and creativity. International Journal of Contemporary Hospitality Management, vol. 28, no. 5, pp. 969-987. DOI : 10.1108/IJCHM-10-2014-0513.

Wang P.Q., Kim P.B., Milne S. (2017). Leader-member exchange (LMX) and its work outcomes: The moderating role of gender. Journal of Hospitality Marketing and Management, vol. 26, no. 2, pp. 125-143. https://doi.org/10.1080/19368623.2016.1185989.

Wollack S., Goodale J.G., Wijting J.P., Smith P.C. (1971). Development of the survey of work values. Journal of Applied Psychology, vol. 55, no. 4, pp. 331-338. https://doi.org/10.1037/h0031531.

\section{Источники}

Aiken L.S., West S.G., Reno R.R. (1991). Multiple regression: Testing and interpreting interactions. California: SAGE.

Akbaş H.E., Bozkurt S., Oktay S., Yılmazer S. (2020). Analyzing the effect of corporate social responsibility perception on organizational identification from employee perspective (pp. 65-81). In I. Altinbasak-Farina, S. Burnaz (Eds.). Ethics, social responsibility and sustainability in marketing, accounting, finance, sustainability, governance \& fraud: Theory and application. Singapore: Springer.

Albert S., Ashforth B.E., Dutton J.E. (2000). Organizational identity and identification: Charting new waters and building new bridges. Academy of Management Review, vol. 25, no. 1, pp. 13-17. https://doi.org/10.5465/amr.2000.2791600.

Almeida L., Pinto H.R. (2005). Life values inventory: Portuguese adaptation studies. Psychological Analysis, vol. 23, no. 2, pp. 28-34.

Al-Zoubi M. (2016). Work values of Jordanian fresh graduates. International Journal of Business and Management, vol. 11, no. 7, pp. 237-244. DOI:10.5539/ijbm.v11n7p237.

Ashforth B.E., Mael F. (1989). Social identity theory and the organization. Academy of Management Journal, vol. 14, no. 1, pp. 20-39. https://doi.org/10.2307/258189.

Bayar L.S. (2016). Demografik faktörlerin iş değerleri üzerine etkisi; İşçi sendikaları üzerine bir araştırma [The effect of demographic factors on work values level: A research on labour unions]. Adnan Menderes Üniversitesi Sosyal Bilimler Enstitüsü Dergisi - Adnan Menderes University Journal of Social Sciences Institute, vol. 3, no. 1, pp. 37-67. (in Turkish). https://doi. org/10.30803/adusobed.188788. 
Blau P.M. (1964). Exchange and power in social life. New York: J. Wiley.

Brown D. (1995). A values-based approach to facilitating career transitions. Career Development Quarterly, vol. 44, issue 1, pp. 4-11. https://doi.org/10.1002/j.2161-0045.1995.tb00524.x.

Cennamo L., Gardner D. (2008). Generational differences in work values, outcomes and person-organization values fit. Journal of Managerial Psychology, vol. 23, no. 8, pp. 891-906. https://doi.org/10.1108/02683940810904385.

Cha J., Borchgrevink C.P. (2018). Leader-member exchange (LMX) and frontline employees' service-oriented organizational citizenship behavior in the foodservice context: Exploring the moderating role of work status. International Journal of Hospitality and Tourism Administration, vol. 19, issue 3, pp. 233-258. https://doi.org/10.1080/15256480.2017.1324337.

Cheney G. (1983). On the various and changing meanings of organizational membership: A field study of organizational identification. Communication Monographs, vol. 50, issue 4, pp. 342-362. https://doi.org/10.1080/03637758309390174.

Cheney G., Tompkins P.K. (1987). Coming to terms with organizational identification and commitment. Central States Speech Journal, vol. 38, issue 1, pp. 1-15. https://doi.org/10.1080/10510978709368225.

Dienesch R.M., Liden R.C. (1986). Leader-member exchange model of leadership: A critique and further development. Academy of Management Review, vol. 11, no. 3, pp. 618-634. https://doi.org/10.2307/258314.

Dose J.J. (1999). The relationship between work values similarity and team-member and leader-member exchange relationships. Group Dynamics: Theory, Research, and Practice, vol. 3, no. 1, pp. 20-32. https://doi.org/10.1037/1089-2699.3.1.20.

Edwards M.R. (2005). Organizational identification: A conceptual and operational review. International Journal of Management Reviews, vol. 7, issue 4, pp. 207-230. https://doi.org/10.1111/j.1468-2370.2005.00114.x.

Elizur D., Borg I., Hunt R., Beck I.M. (1991). The structure of work values: A cross cultural comparison. Journal of Organizational Behavior, vol. 12, issue 1, pp. 21-38. https://doi.org/10.1002/job.4030120103.

Erden-Ayhün S. (2013). Kuşaklar arasındaki farklılıklar ve örgütsel yansımaları [Differences between generations and organizational effects]. Ekonomi ve Yönetim Araştırmaları Dergisi - Journal of Economics and Management Research, vol. 2, no. 1, pp. 93-112. (in Turkish)

Erdogan B., Kraimer M.L., Liden R.C. (2004). Work value congruence and intrinsic career success: The compensatory roles of leader-member exchange and perceived organizational support. Personnel Psychology, vol. 57, issue 2, pp. 305-332. https:// doi.org/10.1111/j.1744-6570.2004.tb02493.x.

Eşitti B. (2018). Konaklama işletmelerinde iş değerlerinin işten ayrılma niyetine etkileri: İş-aile-iş çatışmasının aracı rolü [The effects of work values on intention to leave in accommodation businesses: The mediating role of work-family-work conflict]. Verimlilik Dergisi - Journal of Productivity, no. 3, pp. 235-257. (in Turkish)

Farrell M.A., Oczkowski E. (2012). Organisational identification and leader member exchange influences on customer orientation and organizational citizenship behaviors. Journal of Strategic Marketing, vol. 20, no. 4, pp. 365-377. https://doi.org/10. 1080/0965254X.2011.643917.

Foote N.N. (1951). Identification as the basis for a theory of motivation. American Sociological Review, vol. 16, pp. 14-21. https:// doi.org/10.2307/2087964.

Fornell C., Larcker D.F. (1981). Evaluating structural equation models with unobservable variables and measurement error. Journal of Marketing Research, vol. 18, no. 1, pp. 39-50. https://doi.org/10.2307/3151312.

Graen G.B., Scandura T.A. (1987). Toward a psychology of dyadic organizing (pp. 175-208). In L.L. Cummings, B.M. Staw (Eds.). Research in organizational behavior. Greenwich, CT: JAI Press.

Graen G.B., Uhl-Bien M. (1995). Relationship-based approach to leadership: Development of leader-member exchange (LMX) theory of leadership over 25 years: Applying a multi-level multi-domain perspective. Leadership Quarterly, vol. 6, issue 2, pp. 219-247. https://doi.org/10.1016/1048-9843(95)90036-5.

Gursoy D., Chi C., Karadag E. (2013). Generational differences in work values and attitudes among frontline and service contact employees. International Journal of Hospitality Management, vol. 32, pp. 40-48. https://doi.org/10.1016/j.ijhm.2012.04.002.

Hair J.F., Black W.C., Babin B.J., Anderson R.E. (2009). Multivariate data analysis. Upper Saddle River, NJ: Prentice Hall.

Hayes A.F. (2018). Introduction to mediation, moderation, and conditional process analysis: A regression-based approach ( $2^{\text {nd }}$ ed.). New York, NY: The Guilford.

Hegney D., Plank A., Parker V. (2006). Extrinsic and intrinsic work values: Their impact on job satisfaction in nursing. Journal of Nursing Management, vol. 14, no. 4, pp. 271-281. DOI: 10.1111/j.1365-2934.2006.00618.x.

Hofstede G. (1980). Culture's consequences: International differences in work-related values. Beverly Hills, CA: SAGE.

Hui L., Qun W., Nazir S., Mengyu Z, Asadullah M.A., Khadim S. (2020). Organizational identification perceptions and millennials' creativity: Testing the mediating role of work engagement and the moderating role of work values. European Journal of Innovation Management, Vol. ahead-of-print No. ahead-of-print. https://doi.org/10.1108/EJIM-04-2020-0165.

Kanbur E. (2016). Algılanan örgütsel desteğin çalışanların iç girişimcilik performansları üzerindeki etkisinin incelenmesi [Examining the effects of perceived organizational support on intrapreneurship performance of employees]. Kafkas Üniversitesi Iktisadi ve Idari Bilimler Fakültesi Dergisi-KAÜïBFD - Kafkas University Journal of the Faculty of Economics and Administrative Sciences, vol. 7, no. 14, pp. 443-460. (in Turkish)

Kim M.S., Koo D.W. (2017). Linking LMX, engagement, innovative behavior, and job performance in hotel employees. International Journal of Contemporary Hospitality Management, vol. 29, no. 12, pp. 3044-3062. https://doi.org/10.1108/ IJCHM-06-2016-0319.

Kim P.B., Poulston J., Sankaran A.C. (2017). An examination of leader-member exchange (LMX) agreement between employees and their supervisors and its influence on work outcomes. Journal of Hospitality Marketing and Management, vol. 26, issue 3, pp. 238-258. https://doi.org/10.1080/19368623.2017.1228094. 
Klenke K. (2005). Corporate values as multi-level, multi-domain antecedents of leader behaviors. International Journal of Manpower, vol. 26, no. 1, pp. 50-66. https://doi.org/10.1108/01437720510587271.

Kline R.B. (2015). Principles and practice of structural equation modeling. New York: The Guilford Press.

Kubat U., Kuruüzüm A. (2010). İş değerleri ile kişilik özellikleri arasındaki ilişkinin incelenmesi: Bir yapısal denklem modelleme yaklaşımı [An examination of the relationship between work values and personality traits: A structural equation modeling approach]. Süleyman Demirel Üniversitesi Iktisadi ve Idari Bilimler Fakültesi Dergisi - Suleyman Demirel University the Journal of Faculty of Economics and Administrative Sciences, vol. 15, no. 3, pp. 487-505. (in Turkish)

Lee P.H. (1994). Application of work values to consultation on ways of living. Guidance Quarterly, vol. 30, pp. 33-40.

Liden R.C., Maslyn J.M. (1998). Multidimensionafity of leader-member exchange: An empirical assessment through scale development. Journal of Management, vol. 24, issue 1, pp. 43-72. https://doi.org/10.1177/014920639802400105.

Lin J., Shen P.F., Hsu Y. (2015). Effects of employees' work values and organizational management on corporate performance for Chinese and Taiwanese construction enterprises. Sustainability, vol. 7, pp. 16836-16848.

Lyons S. (2003). An exploration of generational values in life and at work (Unpublished Doctoral Thesis). Carleton University Eric Sprott School of Business, Ottowa, ON.

Lyons S.T., Higgins C.A., Duxbury L. (2010). Work values: Development of a new three-dimensional structure based on confirmatory smallest space analysis. Journal of Organizational Behavior, vol. 31, issue 7, pp. 969-1002. https://doi.org/10.1002/ job.658.

Mael F.A., Ashforth B.E. (1992). Alumni and their alma mater: A partial test of the reformulated model of organizational identification. Journal of Organizational Behaviour, vol. 13, issue 2, pp. 103-123. https://doi.org/10.1002/job.4030130202.

Markham S.E., Yammarino F.J., Murry W.D., Palanski M.E. (2010). Leader-member exchange, shared values, and performance: Agreement and levels of analysis do matter. The Leadership Quarterly, vol. 21, no. 3, pp. 469-480. https://doi.org/10.1016/j. leaqua.2010.03.010.

O'Brien G.E.,HumphrysP.(1982).The effects of congruencybetween workvalues and perceived jobattributes upon thejob satisfaction of pharmacists. Australian Journal of Psychology, vol. 34, no. 1, pp. 99-101. https://doi.org/10.1080/00049538208254719.

Özer P.S., Eriş E.D., Neczan Ö., Özmen T. (2013). Kuşakların farklılaşan iş değerlerine ilişkin emik bir araştırma [An emic research on generational differences in work values]. Dumlupınar Üniversitesi Sosyal Bilimler Dergisi - Dumlupınar University Journal of Social Sciences, vol. 38, pp. 123-142. (in Turkish)

Özkan Ç., Gümüş M. (2013). Ege Bölgesindeki 4-5 yıldızlı otel işletmelerinde örgüt kültürünün iş değerlerinin dönüşümüne etkileri [In the Aegean Region 4-5 star hotel business organizational culture effects of work values transformation]. KMÜ Sosyal ve Ekonomik Araştırmalar Dergïsi - KMU Journal of Social and Economics Research, vol. 15, pp. 01-14. (in Turkish)

Özkan S. (2010). Illköğretim okulu öğretmenlerinin örgütsel bağlılığı ve iş değerleri [The organizational commitment and work values of primary school teachers] (Unpublished master thesis). Mersin University Social Sciences Institution, Mersin.

Öztürk İ. (2019). Kuşaklararası iş değerleri ve örgütsel bağlılık ilişkisi: Vakıf üniversitelerinde bir inceleme [The relationship between intergenerational business values and organizational commitment: $A$ study in foundation universities]. Istanbul Ticaret Üniversitesi Sosyal Bilimler Dergisi - Istanbul Commerce University Journal of Social Sciences, vol. 18, issue 35, pp. 179-191. (in Turkish)

Polat M., Meydan C.H. (2010). Örgütsel özdeşleşmenin sinizm ve işten ayrılma niyeti ile ilişkisi üzerine bir araştırma [An empirical study on the relationship of organizational identification with cynicism and intention to leave]. Savunma Bilimleri Dergisi - The Journal of Defense Sciences, vol. 9, no. 1, pp. 145-172. (in Turkish)

Posner B.Z., Randolph W.A., Schmidt W.H. (1987). Managerial values across functions: A source of organizational problems. Group \& Organization Studies, vol. 12, no. 4, pp. 373-385. https://doi.org/10.1177/105960118701200402.

Pratt M.G. (1998). To be or not to be: Central questions in organizational identification (pp. 171-207). In D.A. Whetten, P.C. Godfrey (Eds.). Identity in organizations: Building theory through conversations. Thousand Oaks, CA: SAGE.

Rokeach M. (1973). The nature of human values. New York: The Free Press.

Ros M., Schwartz S.H., Surkiss S. (1999). Basic individual values, work values, and the meaning of work. Applied Psychology: An International Review, vol. 48, no. 1, pp. 49-71. https://doi.org/10.1111/j.1464-0597.1999.tb00048.x.

Schein E.H. (2010). Organizational culture and leadership (4th ed.). San Francisco, CA: Jossey-Bass.

Schwartz S.H. (1999). A theory of cultural values and some implications for work. Applied Psychology: An International Review, vol. 48, no. 1, pp. 23-47. https://doi.org/10.1111/j.1464-0597.1999.tb00047.x.

Schwartz S.H., Bilsky W. (1987). Toward a universal psychological structure of human values. Journal of Personality and Social Psychology, vol. 53, no. 3, pp. 550-562. https://doi.org/10.1037/0022-3514.53.3.550.

Sparrowe R.T., Liden R.C. (2005). Two routes to influence: Integrating leader-member exchange and social network perspectives. Administrative Science Quarterly, vol. 50, issue 4, pp. 505-535. https://doi.org/10.2189/asqu.50.4.505.

Tajfel H. (1978). Differentiation between social groups: Studies in the social psychology of intergroup relations. London: Academic Press.

Tajfel H., Turner J.C. (1979). An integrative theory of inter-group conflict (pp. 33-47). In W.G. Austin, S. Worchel (Eds.). The social psychology of inter-group relations. Monterey, CA: Brooks/Cole.

Tak B., Aydemir B.A. (2004). Örgütsel özdeşleşme üzerine iki görgül çalışma [Two empirical studies on organizational identification]. 12. National Administrative and Organization Congress, Uludağ University, Bursa.

Tangirala S., Green S.G., Ramanujam R. (2007). In the shadow of the boss's boss: Effects of supervisors' upward exchange relationships on employees. Journal of Applied Psychology, vol. 92, issue 2, pp. 309-320. https://doi.org/10.1037/0021-9010.92.2.309. 
Taş H.Y., Demirdöğmez M., Küçükoğlu M. (2017). Geleceğimiz olan Z kuşağının çalışma hayatına muhtemel etkileri [Possible effects of future architects' Z generation on business life]. OPUS - Uluslararası Toplum Araştırmaları Dergisi - International Journal of Society Researches, vol. 7, pp. 1031-1048. (in Turkish)

Taştan S. (2012). Bir pozitif psikoloji kavramı olarak örgütle özdeşleşmenin psikolojik güçlendirme algısı ve gönüllü performans davranışı arasındaki ilişkide ara değişken rolünün değerlendirilmesi: Gıda sektöründe yapılan bir araştırma [The examination of the moderating role of organizational identification as being a positive psychology concept on the relationship between psychological empowerment and voluntary performance behavior: A research in food sector]. Organizasyon ve Yönetim Bilimleri Dergisi - The Journal of Organization and Management Sciences, vol. 4, pp. 227-238. (in Turkish)

Twenge J.M., Campbell S.M., Hoffman B.J., Lance C.E. (2010). Generational differences in work values: Leisure and extrinsic values increasing, social and intrinsic values decreasing. Journal of Management, vol. 36, issue 5, pp. 1117-1142. https://doi. org/10.1177/0149206309352246.

Üçler Ç. (2018). Investigating the relations of psychological contract, organizational transparency and leader member exchange with employee performance behaviors (Unpublished doctoral thesis). Marmara University Social Sciences Institution, İstanbul.

Van Dick R. (2001). Identification in organizational contexts: Linking theory and research from social and organizational psychology. International Journal of Management Reviews, vol. 3, issue 4, pp. 265-283. https://doi.org/10.1111/1468-2370.00068.

Vurgun L., Öztop S. (2011). Yönetim ve örgüt kültüründe değerlerin önemi [Significance of values for management and organizational culture]. Suleyman Demirel University The Journal of Faculty of Economics and Administrative Sciences, vol. 16, pp. 217-230.

Wang C.J. (2016). Does leader-member exchange enhance performance in the hospitality industry? The mediating roles of task motivation and creativity. International Journal of Contemporary Hospitality Management, vol. 28, no. 5, pp. 969-987. DOI : 10.1108/IJCHM-10-2014-0513.

Wang P.Q., Kim P.B., Milne S. (2017). Leader-member exchange (LMX) and its work outcomes: The moderating role of gender. Journal of Hospitality Marketing and Management, vol. 26, no. 2, pp. 125-143. https://doi.org/10.1080/19368623.2016.1185 989.

Wollack S., Goodale J.G., Wijting J.P., Smith P.C. (1971). Development of the survey of work values. Journal of Applied Psychology, vol. 55, no. 4, pp. 331-338. https://doi.org/10.1037/h0031531.

\section{Information about the authors Информация об авторах}

\section{Merve Karahan}

PhD Candidate in Organizational Behavior, Business Dept. Marmara University (34722 Göztepe Campus, Kadıköy, Istanbul, Turkey). E-mail: merve_karahan@windowslive.com.

\section{Serdar Bozkurt}

PhD, Associate Professor of Business Administration Dept. Yildiz Technical University (34210 Davutpaşa Campus, Esenler, Istanbul, Turkey). E-mail: serdarbozkurt34@gmail.com. (1)

\section{Мерве Карахан}

Соискатель степени PhD (организационное поведение), кафедра бизнеса. Университет Мармара (34722, Турция, г. Стамбул, р-н Кадыкёй, кампус Гёзтепе). E-mail: merve_karahan@windowslive.com.

\section{Сердар Бозкурт}

$\mathrm{PhD}$, доцент кафедры бизнес-администрирования. Технический университет Йылдыз (34210, Турция, г. Стамбул, р-н Эсенлер, кампус Давутпаша). E-mail: serdarbozkurt34@gmail.com. 